\title{
Expectations of Incoming Freshmen in Tertiary Education
}

\author{
Camille N. Dumpang ${ }^{1}$ and Chrisafe Cyril N. Daga ${ }^{2}$ \\ ${ }^{1}$ College of Education, Leyte Normal University, Tacloban City,6500, Philippines \\ (camille.dumpang@lnu.edu.ph) \\ ${ }^{2}$ College of Education, Leyte Normal University, Tacloban City,6500, Philippines \\ (chrisafecyril.daga@lnu.edu.ph)
}

\begin{abstract}
Every year, a new set of high school graduates take the opportunity to enroll themselves in tertiary education. This school year, the Philippine education is to cater tertiary education to the pioneering graduates of the newly implemented K-12 curriculum. This study aimed to explore the expectations of incoming freshmen students in their enrollment in a tertiary education institution. A case study design was employed in the study. Colaizzi method was used in the analysis of the data that were gathered. The students expected several things that were categorized into several themes. Quality education, good moral character, and engaging activities were some of the themes that emerged. The result of the study will be used as the basis for the improvement of the service of the institution.
\end{abstract}

Keywords: Case Study; Colaizzi Method; Tertiary Education

\section{Introduction}

Everyone is entitled to have their expectations when it comes to education. Students have positive perceptions of higher education, but also a clear expectation in the mind of what institution should provide to support and enable their learning and enhance their career prospects (Camille \& Mawer, 2013). Many expectations are admittedly very high. However, it is both the teacher's and student's responsibility to meet the expected outcome of the students because at the end of the day finding a good job and living a good life is the bottom line after education.

Higher education is an extremely important life-changing time for most students. Students invest not only financially, but also emotionally as well as time and effort (Hassel \& Ridout, 2018). Collegiality within and between institutions secondary and tertiary - and student's best interests should underscore the activities of all 'teachers' to help ease the transition dilemmas that are faced by the first-year students (Kantasis). Adjustment happens in their first year, they need to earn trust and confidence from the people that surround them. Way back before they enter tertiary education, they have the ir friends with them and had already established trust and confidence but entering tertiary education is quite more different because the school will expect you something more different and students must meet the standard of a particular school.

\section{Literature Review}

Every school's achievements are also based on the students. Every school must accept students' expectations for improvement and success. The school should have feedbacks and actions to meet students' expectations. Issues relating to feedback emerged as a consistent point of the discrepancy between student expectations, and student and teacher experience (Monaco \& Martin, 2007). Students who had more complex expectations tended to report having more information about classes, professors, social life, and life in general at college and were more satisfied with the amount of information they had than were students with simpler expectations (S. Mark, Hunsberger, Pratt, \& Alisat, 2000).

According to Monaco \& Martin (2007), suggestions for improvements are equally important and should be written in a positive and constructive voice. If universities offer opportunities for learners to be able to express their expectations and then use the students' answers as the basis of constructive discussion between employees and students, there should be a more positive alignment between perceived expectations and levels of student satisfaction with the quality of their experience (Crisp, et al., 2009). One of the factors to which difficulties in adjusting to university have been attributed is the discrepancy between the expectations about university life that students have before starting their studies and their experience after they have begun their university careers. (S. Mark, Hunsberger, Pratt, \& Alisat, 2000).

Scutter, Palmer, da Silva, Lezeckyj, \& Brinkworth (2011) found that students with more complex expectations about university tended to adjust better to stressful circumstances than did students who had simpler expectations. When students enroll at university, there is an expectation from the staff that students will make the adjustments from the high school or their current working situation to their higher education institution.

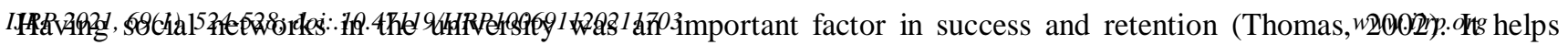
students to have more confidence and gain more friends by connecting with other people by the use of social networks. 
Nicol \& Macfarlane-Dick (2005) stated that if students are to be prepared for learning throughout life, they must be provided with opportunities to develop the capacity to regulate their learning as they progress through higher education.

\section{Research Problem}

The study aims to answer the following questions:

1. Why did you decide to enroll in tertiary education?

2. What do you expect from the university as a new college student?

\section{Theoretical Framework}

This study is anchored on the Rational Expectation Theory. It is defined as expectations as being the best guess of the future (the optimal forecast) that uses all available information.

Rational expectations theories were developed to perceived flaws in theories based on adaptive expectations. Under adaptive expectations, expectations of the future value of an economic variable are based on past values.

\section{Methodology}

This study is a single-case study that helps describe the intervention or phenomenon and the real-life context. The case study methodology by Yin (1994) was employed in this study which included four stages: (1) designing the case study protocol which is done in the first phase of the study, (2) conducting the actual case study, (3) analyzing the case study evidence and (4) developing conclusions, recommendations, and implications based on the evidence gathered.

Interview procedures were used to enable researchers to develop first person descriptions of diverse human experiences (Polkinghorne, 1989; Kvale, 1996; Thomas and Pollio, 2002).

\subsection{Research Design}

Using qualitative single-case study design, this type of case study is used to describe an intervention or phenomenon and the real-life context in which it occurred (Yin, 2003). This study aims to determine the expectations of incoming freshmen of tertiary from the random students.

\subsection{Data Collection}

To gather the data for this study, a carefully structured interview guide questions were prepared by the researchers to elicit necessary information about the expectations of the incoming freshmen of tertiary education. Upon meeting the participants, the researchers explained to them our intention about gathering data regarding their expectations of becoming freshmen in tertiary education. Answers were recorded and transcribed with their permission.

\subsection{Data Analysis}

The main analysis technique employed is through thematic analysis. The participant's responses were coded and analyzed through the aid of Braun and Clarke's thematic analysis (2006). The thematic analysis takes in cutting across data and searching for patterns and themes (Bondas, 2013). Thematic analysis is performed through the process of coding in six phases: (1) familiarization with data, (2) generating initial codes, (3) searching for themes among codes, (4) reviewing themes, (5) defining and naming themes, and (6) producing the final report- to create established, meaningful patterns In analyzing qualitative data, the thematic analysis offers an accessible and theoretically flexible approach (Braun \& Clarke, 2006).

\subsection{Ethical Considerations}

Using qualitative single-case study design, this type of case study is used to describe an intervention or phenomenon and the real-life context in which it occurred (Yin, 2003). This study aims to determine the expectations of incoming freshmen of tertiary from the random students.

\subsection{Triangulation}

To validate the result of this study, the researchers conducted a focused group discussion with the participww.ijrp.org

To validate the result of this study, the researchers conducted a focused group discussion with the participants concerning the expectations of incoming freshmen of tertiary education. Documentation and recording of the actual interview were done by the researchers. 


\section{Results and Discussion}

Thematic analysis on the data gathered revealed 2 major themes based on the expectations of incoming freshmen of tertiary education. Each theme was labeled based on the answers of the participant in describing specific meanings. It is understood that the themes constructed, however, are not held in abeyance as independent of each other but as interrelated aspects of a single over-all pattern or gestalt. The six major themes are as follows:

Fig. 1. Theme 1: Reasons why they enrol in tertiary education

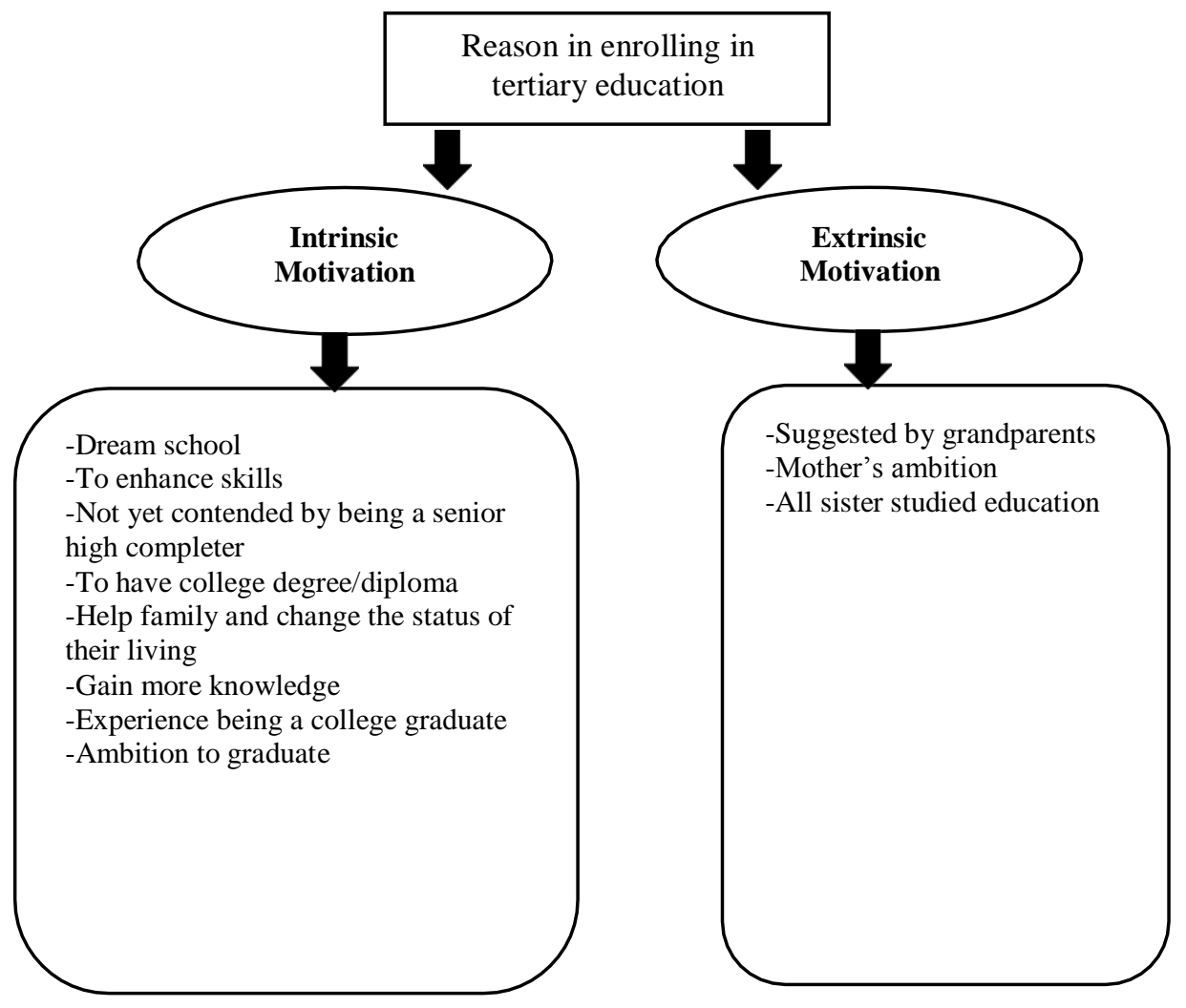

Motivation is the reason for people's actions, desires, and needs (https://en.wikipedia.org/wiki/Motivation). Each student has their motivation upon entering university. Most of the students have their intrinsic motivation which is naturally satisfying by themselves in becoming a college student. Other motivations are coming from the people close to them which they want to satisfy. Based on the interview, many students clarified that the university they are entering is their dream school which motivates them. The transcribed interview follows:

“.......this is my dream school talaga maam maaram ako nga makakabulig hit university ha akon para maging maupay ba it akon magiging future someday, ngan maaram ako maam nga mahahatag ngan mafufullfill nira it akon dreams” (P1)

“...... bagat dre pa maam kumpleto an senior high, dapat mayda pa kami mga challenges nga waray pa namon kaagii, kailangan gud namon mag college kay an senior high dre gud worth hin duro bagat high school la ghap” (P1)

“...... I want to help my family, I want to change the standard and status of our living right now and I want to have a better future” (P2) 
Fig. 2. Theme 2: Expectations of incoming freshmen in tertiary education

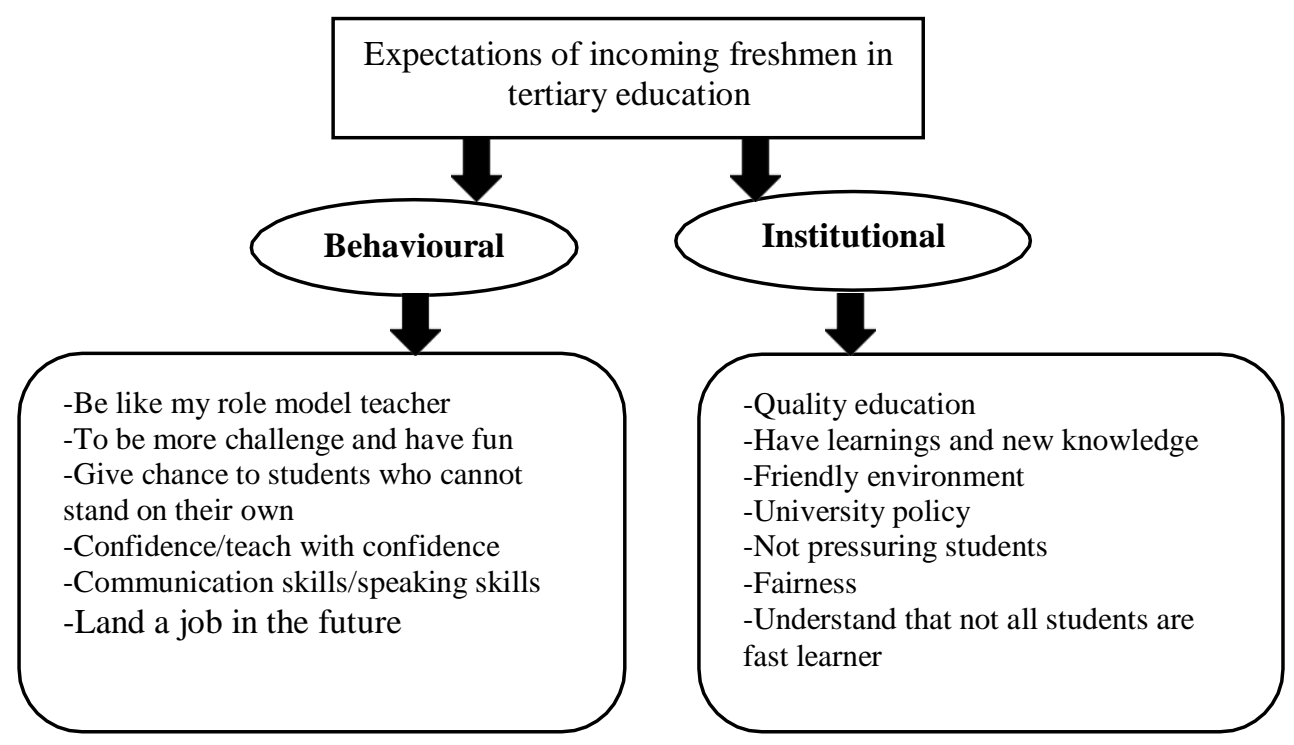

Expectations from students are also important in meeting the standard of every school. A belief that someone will or should achieve something (https://en.oxforddictionaries.com/definition/expectation) Students' expectations are not only from their extent but the expectation for the university they are entering. One of them wanted to be like his favorite teacher who was a graduate of the same university. They are also expecting to be challenged but also to enjoy while learning. Quality education is the most expected of the students from the university in a way that they will not be pressured and they wanted to let the school that not every student is a fast learner. Transcribed interview from the students are as follow:

“..... maging inspiration hira para ha amon nga maging maupay it amon pag eskwela, ngan makahatag hira ha amon hin quality education" (P1)

“. . . my expectation is tagan hin pansin an mga estudyante nga dre kaya mag stand out para ha ira sarili .... ”(P2)

“......I'm expecting this university to give a good quality education.” (P2)

“...... ang ineexpect ko po dito sa LNU ay yung mabigyan kami ng kind of quality education na hinahanap naming mga estudyante and I also expect na sana hindi lang kami ang mabigyan ng hinahangad naming education pati rin yung mga nangangarap...." (P2)

“....I expect that this school will fully develop my skill in teaching at sana po mababait po ang mga teacher at fair” (P2)

“..... I'm expecting this university to help our speaking skills ngan ma-boost it amon confidence, maghatag hn good quality education" (P3)

\section{Summary}

The researchers found out the reasons why students still wanted to enroll in tertiary education and their expectations as incoming freshmen in tertiary education. They enroll in tertiary education because some of them dreamt of being a student of the said university, they wanted to enhance their skills, to learn more, to have a college degree, to experience being a college graduate, to help improve the status of their living and some of them stated that they are still not contented of just being a senior high school completer. Students have a lot of expectations to be expected some of which are a good quality education from the university, have learnings and new knowledge teacher, to be more challenge and have fun, to let teachers give chance to students who cannot stand on their own, to be more confident, to improve communication skills/speaking skills, to have a friendly environment and to experience fairness. Those are from the random students who wanted to be a university student.

\section{Conclusion}

Students have common reasons and expectations in entering tertiary education. They have already many experiences in their previous institution and they still wanted to improve and enhance more their skills and knowledge. They are not yet 
contented with just being a senior high completer though they have already experienced a lot of activities, being a college graduate still matter to the participants in this study. Their expectations are also based on their previous experiences, which came from those they experience and they did not yet experience. Meeting these expectations by the university would help in reaching the quality education that the university is offering.

\section{Recommendation}

The following recommendations are made:

1. The school should have actions/feedback about the expectations of the incoming freshmen.

2. Tertiary institutions should provide quality education to satisfy and meet the expectations of the students.

\section{References}

Brinkwok, R., McCan, B., Matthews, C., \& Nordstrom, K. (2008). First year expectations and experiences: student and teacher perspectives. 17.

Camille, K. B., \& Mawer, M. (2013). Student Expectations and Perceptions on Higher Education. King's Learning Institute, 82.

Crisp, G., Palmer, E., Turnbull, D., Nettlebeck, T., Ward, L., LeCouteur, A., . . Schneider, L. (2009). First year student expectations: Results from a university-wide student survey. Journal of University Teaching and Learning Practice, 18.

Dick. (2010). Instructional Design Theory. Retrieved from https://sites.google.com/a/nau.edu/educationallearningtheories/home/instructional-designtheory

Hassel, S., \& Ridout, N. (2018). An Investagation of First-Year Students' and Lecturers Expectations of University Education. (D. Fung, Ed.) Frontiers in Psychology, 13.

https://en.oxforddictionaries.com/definition/expectation. (n.d.).

https://en.wikipedia.org/wiki/Motivation. (n.d.).

Kantasis, T. (n.d.). The role of social transition in student's adjustment to the first-year of university.

Monaco, M., \& Martin, M. (2007). The Millenial Student: A New Generation of Learners. Athletic Training Education Journal, 5.

Nicol, D. J., \& Macfarlane-Dick, D. (2005). Formative assessment and self-regulated learning: A model and seven principles of good feedback practice. Studies in Higher Education.

Rust, C., Price, M., \& O'Donovan, B. (2003). Improving Students' Learning by Developingtheir Understanding of Assessment Criteria and Processes. Assessment \& Evaluation in Higher Education.

S. Mark, P., Hunsberger, B., Pratt, M. W., \& Alisat, S. (2000). Cognitive Complexity of Expectations and Adjustment to University in the First Year. Journal of Adolescent Research, 20.

Scutter, S., Palmer, E., da Silva, K., Lezeckyj, A., \& Brinkworth, R. (2011). What do commencing undergraduate stdents expect from first year university. The International Journal of the First Year in th Higher Education, 13.

Thomas, L. (2002). Student Retention in Higher Education: The Role of Institutional Habitus. Journal of Education Policy.

Yin, R. K. (2003). Case Study Research: Design and Methods. Sage. 